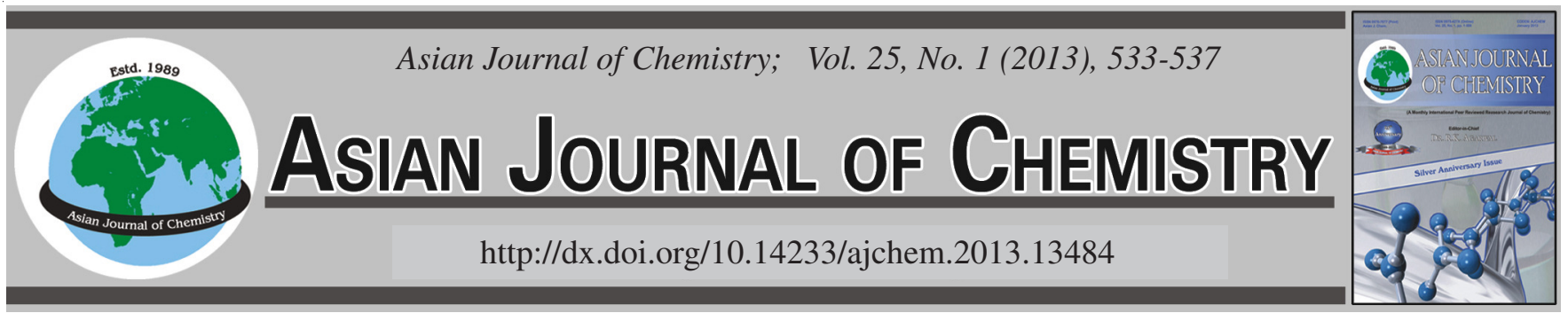

\title{
Synthesis, Characterization and Antimicrobial Studies of Novel \\ Binuclear Transition Metal Complexes of Schiff Base Derived from 1-Amino-5-methyl-2,6-pyrimidine-dione and 2,3-Butanedione
}

\author{
Netra Pal Singh ${ }^{*}$ and Abhay Nanda Srivastava
}

Department of Chemistry, Meerut College, Meerut-250 001, India

*Corresponding author: E-mail: npsmcm.in@gmail.com

\begin{abstract}
A series of binuclear transition metal complexes of the type $\left.\left[\mathrm{M}_{2}(\mathrm{~L})_{2} \mathrm{X}_{4}\right)\right] \cdot \mathrm{nH}_{2} \mathrm{O}$ (where, $\mathrm{M}=\mathrm{Cu}$ (II), $\mathrm{Ni}$ (II), $\mathrm{Co}$ (II) or $\mathrm{Zn}(\mathrm{II}), \mathrm{X}=\mathrm{Cl}^{-} /$ $\mathrm{CH}_{3} \mathrm{COO}^{-}$and $\mathrm{L}=$ ligand) of a Schiff base ligand derived from 1-amino-5-methyl-2,6-pyrimidine-dione and 2,3-butanedione have been synthesized and characterized by elemental analysis, molar conductance measurements, magnetic moment measurements, IR, UV-visible, ${ }^{1} \mathrm{H}$ NMR, EPR and mass spectral studies. Electronic spectral data and magnetic moment values indicate octahedral geometry for all the metal complexes. In vitro antimicrobial activity of ligand and its metal complexes were also studied against bacteria (Bacillus subtilis and Escherichia coli) and fungi (Aspergillus niger and Aspergillus flavus) which show antimicrobial activity of ligand and binuclear metal complexes.
\end{abstract}

Key Words: Octahedral metal complexes, Amino-pyrimidine, Antimicrobial activity, Schiff base.

ᄂ - - - - - - - - - - - - - - - - - - - - - - - - -

\section{INTRODUCTION}

Pyrimidines, being an integral part of DNA and RNA, play an essential role in several biological processes and have considerable chemical and pharmacological importance. Most of the transition metal complexes containing nucleobase ligands or analogs have been used to understand various biological phenomena as well as to get new biologically active metallodrugs ${ }^{1,2}$. Due to multifunctional coordinating ability of pyrimidines and its derivatives, they have been used for synthesis of mononuclear and binuclear transition metal complexes $^{3,4}$. The enormous interest in the field of coordination chemistry of transition metal ions with Schiff bases is due to variety of applications of these compounds in biological, clinical, analytical and pharmacological areas ${ }^{5,6}$. Recently, some of the Schiff base complexes possessing potent antibacterial activities have been reported ${ }^{7}$. Some other transition metal complexes have also been synthesized recently which show good biological activities viz. antimicrobial, DNA interaction and antitumor ${ }^{8,9}$. In view of these importance of metal complexes, we report herein preparation, characterization and in vitro antimicrobial activity of binuclear transition metal complexes of a novel Schiff base ligand derived from 1-amino-5-methyl2,6-pyrimidine-dione and 2,3-butanedione.

\section{EXPERIMENTAL}

All the chemicals used were of analytical reagent grade and used as received. 2,3-Butanedione (Sigma-Aldrich), hydrated metal salts, methanol, ethanol and diethyl ether (Qualigens). 1-Amino-5-methyl-2,6-pyrimidine-dione was synthesized according to the method reported in literature ${ }^{10}$. Elemental analysis $(\mathrm{C}, \mathrm{H}, \mathrm{N})$ were performed using a VarioEL elementar analysensysteme. Metals and chlorides were determined volumetrically ${ }^{11}$ and gravimetrically ${ }^{12}$. IR spectra were recorded using $\mathrm{KBr}$ discs $\left(4000-400 \mathrm{~cm}^{-1}\right.$ ) on a Shimadzu 8300 IR spectrophotometer. Electronic absorption spectra in the 200$900 \mathrm{~nm}$ range were obtained in DMF on a Systronic UV-visible spectrophotometer. ${ }^{1} \mathrm{H}$ NMR spectra (at room temperature) (in DMSO- $d_{6}$ ) was recorded on a Bruker Avance II 400 NMR spectrometer with reference to TMS $(0.0 \mathrm{ppm})$. The FAB mass spectra were recorded on a JEOL SX 102/DA-6000 mass spectrometer/data system using argon/xenon $(6 \mathrm{kV}, 10 \mathrm{ma})$ as the FAB gas. Molar conductance measurements were determined in DMSO $\left(c a \cdot 10^{-3} \mathrm{M}\right)$ at room temperature using a Jenway Model 4070 conductivity meter. Magnetic moment measurement were carried out by the Gouy method using $\mathrm{Hg}\left[\mathrm{Co}(\mathrm{SCN})_{4}\right]$ as calibrant. EPR spectra of $\mathrm{Cu}(\mathrm{II})$ and $\mathrm{Co}(\mathrm{II})$ complexes were recorded as polycrystalline sample on a Varian 
E-112 spectrometer at the X-band region with frequency of 9.1 GHz under the magnetic field strength $3200 \mathrm{G}$ using TCNE (tetracynaoethylene) as field marker $(g=2.0027)$.

Synthesis of the Schiff base ligand (L): To an aqueous ethanolic solution $(20 \mathrm{~mL})$ of 1-amino-5-methyl-2,6-pyrimidine-dione (1.41 g, $10 \mathrm{mmol}), 2,3$-butanedione $(0.87 \mathrm{~mL}, 10$ mmol) was added drop wise. The resulting solution was stirred for $0.5 \mathrm{~h}$ and then refluxed at $65^{\circ} \mathrm{C}$ for $1.5 \mathrm{~h}$. The creamish solid product (L) obtained was filtered off, washed with water, methanol, ethanol and diethyl ether and dried in vacuum desiccator over anhydrous calcium chloride (Scheme-I). Yield $72 \%$; m.p.: $214{ }^{\circ} \mathrm{C}$; creamish solid. Anal. calcd. for $\mathrm{C}_{9} \mathrm{H}_{11} \mathrm{~N}_{3} \mathrm{O}_{3}$ (209.12): C 51.69, H 5.35, N $20.09 \%$. Found: C 51.62, H 5.26, N $20.01 \%$.

Synthesis of binuclear metal complexes (1-4): To a hot aqueous ethanolic solution ( $25 \mathrm{~mL}$ ) of ligand (L) $(2 \mathrm{mmol}$, $0.42 \mathrm{~g}$ ), methanolic solution of $2 \mathrm{mmol}$ of hydrated metal salt $\left[\mathrm{CuCl}_{2} \cdot 2 \mathrm{H}_{2} \mathrm{O}(0.34 \mathrm{~g}), \mathrm{NiCl}_{2} \cdot 6 \mathrm{H}_{2} \mathrm{O}(0.47 \mathrm{~g}), \mathrm{CoCl}_{2} \cdot 6 \mathrm{H}_{2} \mathrm{O}\right.$ $(0.48 \mathrm{~g})$ and $\left.\mathrm{Zn}\left(\mathrm{CH}_{3} \mathrm{COO}\right)_{2} \cdot 2 \mathrm{H}_{2} \mathrm{O}(0.44 \mathrm{~g})\right]$ was added drop wise with constant stirring. The resulting solution mixture was stirred for $1.5 \mathrm{~h}$ and then refluxed for 10-12 h. On cooling this reaction mixture in refrigerator for overnight, solid coloured products were obtained which were filtered off, washed with hot water, methanol, ethanol and diethyl-ether and dried in vacuum desiccator over anhydrous calcium chloride (Scheme-II).

Complex (1) $\left[\mathrm{Cu}_{2}(\mathbf{L})_{2} \mathbf{C l}_{4}\right] \cdot \mathbf{4} \mathbf{H}_{2} \mathrm{O}$ : Yield 64\%; m.p.: $242{ }^{\circ} \mathrm{C}$ (dec.); dark brown solid. Anal. calcd. for $\mathrm{C}_{18} \mathrm{H}_{30} \mathrm{~N}_{6} \mathrm{O}_{10} \mathrm{Cu}_{2} \mathrm{Cl}_{4}$ (759.54): C 28.46, H 4.26, N 11.06, Cu 16.73, Cl $18.69 \%$. Found: C 28.35, H 4.14, N 10.94, Cu 16.53, Cl 18.57 \%. Molar conductance $\Lambda_{\mathrm{M}}: 8.5 \Omega^{-1} \mathrm{~cm}^{2} \mathrm{~mol}^{-1} \cdot \mu_{\mathrm{eff}}: 1.56 \mu_{\mathrm{B}}$. UV-VIS (DMF), $\lambda_{\max }: 354,580,734 \mathrm{~nm}$.
Complex (2) $\left[\mathrm{Ni}_{2}(\mathrm{~L})_{2} \mathrm{Cl}_{4}\right] \cdot 4 \mathrm{H}_{2} \mathrm{O}$ : Yield $68 \%$; m.p.: $236^{\circ} \mathrm{C}$ (dec.); brown solid. Anal. calcd. for $\mathrm{C}_{18} \mathrm{H}_{30} \mathrm{~N}_{6} \mathrm{O}_{10} \mathrm{Ni}_{2} \mathrm{Cl}_{4}$ (749.90): C 28.82, H 4.03, N 11.21, Ni 15.66, Cl 18.93\%. Found: C 28.79, H 4.00, N 11.17, Ni 15.61, Cl $18.89 \%$. Molar conductance $\Lambda_{\mathrm{M}}: 7.6 \Omega^{-1} \mathrm{~cm}^{2} \mathrm{~mol}^{-1} \cdot \mu_{\mathrm{eff}}: 1.80 \mu_{\mathrm{B}} \mathrm{UV}-\mathrm{VIS}$ (DMF), $\lambda_{\max }: 378,502,690 \mathrm{~nm}$.

Complex (3) $\left[\mathbf{C o}_{2}(\mathbf{L})_{2} \mathbf{C l}_{4}\right] \cdot \mathbf{H}_{2} \mathbf{O}$ : Yield $61 \%$; m.p.: $254^{\circ} \mathrm{C}$ (dec.); reddish brown solid. Anal. calcd. for $\mathrm{C}_{18} \mathrm{H}_{24} \mathrm{~N}_{6} \mathrm{O}_{7} \mathrm{Co}_{2} \mathrm{Cl}_{4}$ (696.30): C 31.05, H 3.47, N 12.07, Co 16.93, Cl 20.40\%. Found: C 30.98, H 3.36, N 12.01, Co 16.88, Cl 20.23\%. Molar conductance $\Lambda_{\mathrm{M}}: 5.2 \Omega^{-1} \mathrm{~cm}^{2} \mathrm{~mol}^{-1}$. $\mu_{\text {eff }}: 2.62 \mu_{\mathrm{B}}$ UV-VIS (DMF), ; $\lambda_{\max }: 382,456,598,780 \mathrm{~nm}$.

Complex (4) $\left[\mathrm{Zn}_{2}(\mathrm{~L})_{2}\left(\mathrm{CH}_{3} \mathrm{CO}_{2}\right)_{4}\right] \cdot \mathbf{4} \mathrm{H}_{2} \mathrm{O}$ : Yield $67 \%$; m.p.: $232^{\circ} \mathrm{C}$ (dec.); colourless. Anal. calcd. for $\mathrm{C}_{26} \mathrm{H}_{42} \mathrm{~N}_{6} \mathrm{O}_{18} \mathrm{Zn}_{2}$ (857.38): C 36.42, H 4.94, N 9.80, Zn $16.18 \%$. Found: C 36.31, H 4.82, N 9.70, Zn 16.06 \%. Molar conductance $\Lambda_{\mathrm{M}}$ : $3.4 \Omega^{-1} \mathrm{~cm}^{2} \mathrm{~mol}^{-1}$. UV-VIS (DMF), $\lambda_{\max }: 372 \mathrm{~nm}$.

In vitro antibacterial and antifungal activity: Synthesized compounds were evaluated for their in vitro antibacterial activity against $B$. subtilis and $E$. coli and antifungal activity against $A$. niger and $A$. flavus by the agar-well diffusion method $^{13}$ at the concentration of 500 and $100 \mu \mathrm{g} \mathrm{mL}^{-1}$ of each chemical compound. Bacteria were inoculated into Nutrient Broth (Difco) and incubated for $30 \mathrm{~h}$ and the fungi studied incubated in Malt Extract Broth (Difco) for $54 \mathrm{~h}$. The dilution plate method was used to enumerate microorganism $\left(10^{5}\right.$ bacteria per $\mathrm{mL}$ and $10^{3}-10^{4}$ fungi per $\mathrm{mL}$ ) for $24 \mathrm{~h}$. By using a sterilize cork borer ( $6 \mathrm{~mm}$ diameter), wells were dug in the culture plates. Compounds dissolved in DMSO were added $(0.2 \mu \mathrm{L})$ to these wells. The Petri dishes were left at $4{ }^{\circ} \mathrm{C}$ for 2 $\mathrm{h}$ and then the plates were incubated at $30^{\circ} \mathrm{C}$ for bacteria $(24$ h) and $25^{\circ} \mathrm{C}$ for fungi $(72 \mathrm{~h}$ ). At the end of the period, inhibition<smiles>Cc1c[nH]c(=O)n(N)c1=O</smiles><smiles>CC(=O)C(C)=O</smiles><smiles>CC(=O)/C(C)=N/n1c(=O)[nH]cc(C)c1=O</smiles>

(L)

Scheme-I: Synthesis of ligand (L)

$\mathrm{EtOH} / \mathrm{H}_{2} \mathrm{O}, \mathrm{MeOH}$,

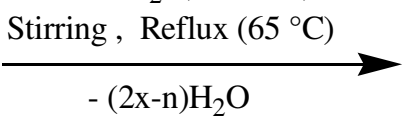

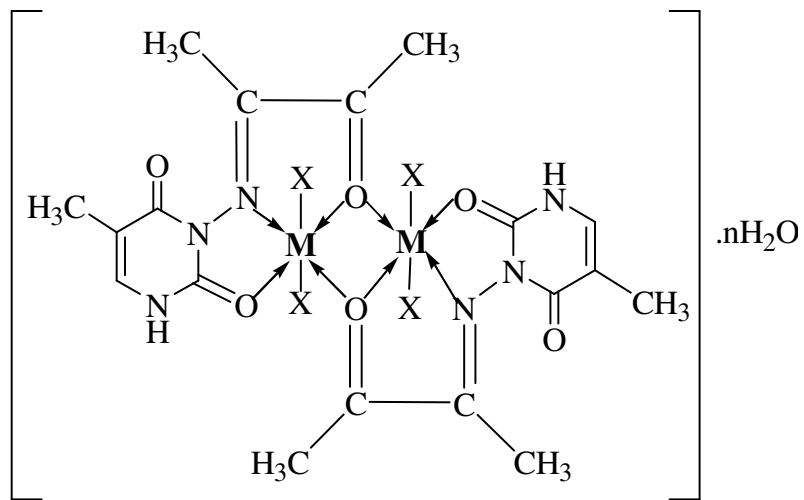

Scheme-II: Synthesis of binuclear metal complexes 
TABLE-1

IR SPECTRAL BAND $\left(v, \mathrm{~cm}^{-1}\right)$ OF THE SCHIFF BASE LIGAND AND ITS METAL COMPLEXES

\begin{tabular}{lcccccc}
\hline \multicolumn{1}{c}{ Compound } & $(-\mathrm{OH}) / \mathrm{H}_{2} \mathrm{O}$ & $(\mathrm{C}=\mathrm{N})$ azo. & $(\mathrm{C}=\mathrm{O})$ & $(\mathrm{N}-\mathrm{C}=\mathrm{O})$ pym. & $(\mathrm{M}-\mathrm{N})$ & \multicolumn{2}{c}{$(\mathrm{M}-\mathrm{O})$} \\
\hline$(\mathrm{L})$ & - & 1612 & 1768 & 1692 & - & - \\
{$\left[\mathrm{Cu}_{2}(\mathrm{~L})_{2} \mathrm{Cl}_{4}\right] \cdot 4 \mathrm{H}_{2} \mathrm{O}$} & 3428 & 1626 & 1592 & 1670 & 478 & 523 \\
{$\left[\mathrm{Ni}_{2}(\mathrm{~L})_{2} \mathrm{Cl}_{4}\right] \cdot 4 \mathrm{H}_{2} \mathrm{O}$} & 3432 & 1620 & 1588 & 1678 & 462 & 506 \\
{$\left[\mathrm{Co}_{2}(\mathrm{~L})_{2} \mathrm{Cl}_{4}\right] \cdot 4 \mathrm{H}_{2} \mathrm{O}$} & 3420 & 1624 & 1592 & 1672 & 475 & 518 \\
{$\left[\mathrm{Zn}_{2}(\mathrm{~L})_{2}\left(\mathrm{CH}_{3} \mathrm{CO}_{2}\right)_{4}\right] \cdot 4 \mathrm{H}_{2} \mathrm{O}$} & 3438 & 1632 & 1588 & 1668 & 488 & 512 \\
\hline
\end{tabular}

TABLE-2

\begin{tabular}{|c|c|}
\hline \multicolumn{2}{|r|}{ 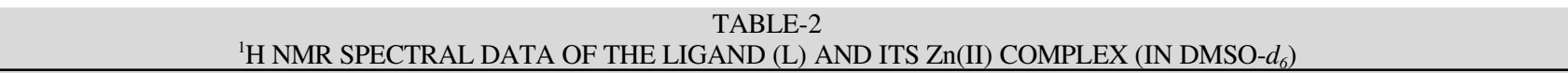 } \\
\hline Compound & ${ }^{1} \mathrm{H}$ NMR $(\delta / \mathrm{ppm})$ \\
\hline$(\mathrm{L})$ & $\begin{array}{l}1.02\left[\mathrm{O}=\mathrm{C}-\mathrm{CH}_{3}(\mathrm{~s}, 3 \mathrm{H})\right], 1.60\left[\mathrm{~N}=\mathrm{C}-\mathrm{CH}_{3}(\mathrm{~s}, 3 \mathrm{H})\right], 1.74\left[-\mathrm{CH}_{3}(\mathrm{~s}, 3 \mathrm{H})\right], 7.36[-\mathrm{CH}(\mathrm{pym} .)(\mathrm{s}, 1 \mathrm{H})], 11.28[-\mathrm{NH} \\
(\mathrm{pym} .)(\mathrm{br}, \mathrm{s}, 1 \mathrm{H}] .\end{array}$ \\
\hline$\left[\mathrm{Zn}_{2}(\mathrm{~L})_{2}\left(\mathrm{CH}_{3} \mathrm{CO}_{2}\right)_{4}\right] \cdot 4 \mathrm{H}_{2} \mathrm{O}$ & $\begin{array}{l}0.90\left[\mathrm{O}=\mathrm{C}-\mathrm{CH}_{3}(\mathrm{~s}, 6 \mathrm{H})\right], 1.12\left[\mathrm{~N}=\mathrm{C}-\mathrm{CH}_{3}(\mathrm{~s}, 6 \mathrm{H})\right], 1.73\left[-\mathrm{CH}_{3}(\mathrm{~s}, 6 \mathrm{H})\right], 2.17\left[-\mathrm{CH}_{3} \mathrm{COO}(\mathrm{br}, \mathrm{s}, 12 \mathrm{H})\right], 3.34 \\
{\left[\mathrm{H}_{2} \mathrm{O}(\mathrm{br}, \mathrm{m}, 8 \mathrm{H})\right], 7.34[-\mathrm{CH}(\mathrm{pym} .)(\mathrm{s}, 2 \mathrm{H})], 10.98[-\mathrm{NH}(\mathrm{pym} .)(\mathrm{br}, \mathrm{s}, 2 \mathrm{H}] .}\end{array}$ \\
\hline
\end{tabular}

zones formed on the medium were evaluated as millimeters $(\mathrm{mm})$ diameter. Biological activity data of all compounds were expressed as percent inhibition over control calculated from the size of inhibition zone. The per cent inhibition was calculated using the formula:

$$
\% \text { Inhibition }=(\mathrm{C}-\mathrm{T}) \times 100 / \mathrm{C}
$$

where $\mathrm{C}$ is the diameter of the microbial colony in the control plate and $\mathrm{T}$ is the diameter of the microbial colony in the tested plate after same incubation period.

\section{RESULTS AND DISCUSSION}

The newly synthesized ligand and binuclear metal complexes are quite stable at room temperature in solid state. Analytical and spectral data are consistent with the proposed molecular formula and structure of the ligand and metal complexes. Molar conductance values (3.4-8.5 $\left.\Omega^{-1} \mathrm{~cm}^{2} \mathrm{~mol}\right)$ in DMSO show that all the complexes are non-electrolyte in nature ${ }^{14}$. An octahedral geometry was assigned for all binuclear metal complexes. The ligand is soluble in common organic solvents but metal complexes are soluble in DMF and DMSO.

IR spectra: The most relevant IR absorption bands from the spectra of the Schiff base ligand (L) and binuclear complexes are given in Table-1. The IR spectrum of ligand (L) shows a band at $1612 \mathrm{~cm}^{-1}$ indicating the presence of azomethine group vibration $v(-\mathrm{C}=\mathrm{N})^{15}$. There is no peak of unreacted $-\mathrm{NH}_{2}$ group in the IR spectra of ligand which indicate the synthesis of proposed ligand. The band in the IR spectra of ligand at $1692 \mathrm{~cm}^{-1}$ is assigned for $(\mathrm{N}-\mathrm{C}=\mathrm{O})$ group of pyrimidine ring ${ }^{16}$. The band at $1768 \mathrm{~cm}^{-1}$ indicate the presence of free ketonic $(-\mathrm{C}=\mathrm{O})$ group of ligand ${ }^{17}$. A band at $3065 \mathrm{~cm}^{-1}$ may be due to stretching vibration of heterocyclic - $\mathrm{NH}$ group of characteristics of pyrimidine ring ${ }^{16}$. The IR spectra of metal complexes show significant changes compared to the free ligand. In the IR spectra of all the complexes bands in the range $3438-3420 \mathrm{~cm}^{-1}$ due to the stretching vibration of $v(\mathrm{OH})$ of water molecule ${ }^{18}$. In the IR spectra of all metal complexes, bands of azomethine group $(-\mathrm{C}=\mathrm{N})$ shifted by $1632-1620 \mathrm{~cm}^{-1}$, suggesting coordination through nitrogen atom of azomethine group $^{19}$. This is further supported by the presence of new bands in the range of 490-475 $\mathrm{cm}^{-1}$ which is assignable to $\mathrm{v}(\mathrm{M}-\mathrm{N})$ vibration $^{20}$. In the IR spectra of binuclear metal complexes, there is no band in the range of $1768 \mathrm{~cm}^{-1}$, so it is clear that the oxygen atom of ketonic carbonyl group has been participated in coordination. The appearance of band in the range 1592$1588 \mathrm{~cm}^{-1}$ indicates the presence of bridging ketonic oxygen atom. The band observed at $1692 \mathrm{~cm}^{-1}$ in free ligand, shifted by $1678-1657 \mathrm{~cm}^{-1}$ in the spectra of metal complexes which are assigned to coordinated $(\mathrm{N}-\mathrm{C}=\mathrm{O})$ group of pyrimidine ring $^{21}$. Coordination through oxygen atom of carbonyl group is further proved by the appearance of new band in the region of 536-506 $\mathrm{cm}^{-1}$ which may be assigned for $\mathrm{v}(\mathrm{M}-\mathrm{O})$ vibration ${ }^{22}$. In the IR spectrum of $\left[\mathrm{Zn}_{2}(\mathrm{~L})_{2}\left(\mathrm{CH}_{3} \mathrm{CO}_{2}\right)_{4}\right] \cdot 4 \mathrm{H}_{2} \mathrm{O}$ complex two characteristic bands appeared in the range $1560 \mathrm{~cm}^{-1}$ and 1352 $\mathrm{cm}^{-1}$ may be assigned to $\mathrm{v}\left(\mathrm{COO}^{-}\right)$asymmetric and $\mathrm{v}\left(\mathrm{COO}^{-}\right)$ symmetric stretching vibration of acetate ion. A difference between $\left(v_{\mathrm{as}}-V_{\mathrm{s}}\right)$ is $308 \mathrm{~cm}^{-1}$ which is greater than $144 \mathrm{~cm}^{-1}$ indicates the coordination of the acetate ion in unidentate fashion with central metal ion ${ }^{18}$.

${ }^{1}$ H NMR spectra: The ${ }^{1} \mathrm{H}$ NMR spectral data of ligand and its $\mathrm{Zn}$ (II) metal complex were recorded in solvent DMSO$d_{6}$ and given in Table-2. In the ${ }^{1} \mathrm{H}$ NMR spectrum of ligand, no signal observed corresponding to primary amine proton which suggest that formation of ligand. In the ${ }^{1} \mathrm{H}$ NMR spectrum of $\mathrm{Zn}(\mathrm{II})$ complex, the signal of $\left(\mathrm{CH}_{3}-\mathrm{C}=\mathrm{N}\right)$ protons, $\left(\mathrm{CH}_{3^{-}}\right.$ $\mathrm{C}=\mathrm{O}$ ) protons and $(-\mathrm{NH})$ proton of pyrimidine ring shifted compared to the free ligand, suggesting coordination through azomethine nitrogen atom, oxygen atoms of $\left(\mathrm{CH}_{3}-\mathrm{C}=\mathrm{O}\right)$ and $(\mathrm{NH}-\mathrm{C}=\mathrm{O})$ group $^{23}$.

Mass spectra: The FAB mass spectra of ligand and binuclear complexes have been recorded. The proposed molecular formula of these compounds was confirmed by comparing their molecular formula weight with $\mathrm{m} / \mathrm{e}$ values. The molecular ion peaks obtained from various compounds are as follows: (1) $\mathrm{m} / \mathrm{e}=210.01$ [ligand], (2) $\mathrm{m} / \mathrm{e}=760.55$ [Cu(II) complex], (3) m/e = 750.91 [Ni(II) complex], (4) m/e $=697.31[\mathrm{Co}(\mathrm{II})$ complex], (5) $\mathrm{m} / \mathrm{e}=858.24$ [Zn(II) complex]. These data are in good agreement with the proposed molecular formula for these compounds. In addition to the peaks due to the molecular ion, the spectra exhibit peaks assignable to various fragments arising from the thermal cleavage of the complexes. Electronic absorption spectra and magnetic moment measurements

The electronic absorption spectra of binuclear metal complexes were recorded in DMF solution. The electronic absorption spectrum of $\left[\mathrm{Cu}_{2}(\mathrm{~L})_{2} \mathrm{Cl}_{4}\right] \cdot 4 \mathrm{H}_{2} \mathrm{O}$ exhibits bands at $734 \mathrm{~nm}$ and $580 \mathrm{~nm}$ attributed to ${ }^{2} \mathrm{~B}_{1 \mathrm{~g}} \rightarrow{ }^{2} \mathrm{~A}_{1 \mathrm{~g}}$ and ${ }^{2} \mathrm{~B}_{1 \mathrm{~g}} \rightarrow{ }^{2} \mathrm{E}_{\mathrm{g}}$ 
TABLE-3

ANTIBACTERIAL AND ANTIFUNGAL ACTIVITY OF LIGAND AND METAL COMPLEXES (\% INHIBITION)

\begin{tabular}{|c|c|c|c|c|c|}
\hline Compound & Conc. $(\mu \mathrm{g} / \mathrm{mL})$ & B. subtilis & E. coli & A. niger & A. flavus \\
\hline \multirow[t]{2}{*}{ (L) } & 100 & 38 & 52 & 58 & 66 \\
\hline & 500 & 46 & 60 & 68 & 76 \\
\hline \multirow[t]{2}{*}[\mathrm{Cu}_{2}(\mathrm{L})_{2}(\mathrm{Cl})_{4}]{$\cdot 4 \mathrm{H}_{2} \mathrm{O}$} & 100 & 54 & 73 & 80 & 81 \\
\hline & 500 & 62 & 84 & 88 & 87 \\
\hline \multirow[t]{2}{*}[\mathrm{Ni}_{2}(\mathrm{L})_{2}(\mathrm{Cl})_{4}]{$\cdot 4 \mathrm{H}_{2} \mathrm{O}$} & 100 & 49 & 57 & 77 & 73 \\
\hline & 500 & 54 & 64 & 82 & 84 \\
\hline \multirow[t]{2}{*}[\mathrm{Co}_{2}(\mathrm{L})_{2}(\mathrm{Cl})_{4}]{$\cdot \mathrm{H}_{2} \mathrm{O}$} & 100 & 45 & 53 & 66 & 70 \\
\hline & 500 & 51 & 59 & 69 & 72 \\
\hline \multirow{2}{*}[\mathrm{Zn}_{2}(\mathrm{L})_{2}(\mathrm{CH}_{3}\mathrm{CO}_{2})_{4}]{$\cdot 4 \mathrm{H}_{2} \mathrm{O}$} & 100 & 53 & 70 & 74 & 80 \\
\hline & 500 & 60 & 82 & 87 & 85 \\
\hline
\end{tabular}

transitions, respectively. These transitions are consistent with a distorted octahedral geometry of $\mathrm{Cu}(\mathrm{II})$ complex $^{24}$. The spectra of $\mathrm{Cu}(\mathrm{II})$ complex further display a shoulder at $354 \mathrm{~nm}$ assigned to charge transfer transition from the ligand to metal ion $(\mathrm{LMCT})^{24}$. The obtained magnetic moment value $\left(\mu_{\text {eff }}\right)$ for $\mathrm{Cu}(\mathrm{II})$ complex is $1.56 \mu \mathrm{B}$ indicates that magnetic exchange occurs between the two copper sites and also support distorted octahedral geometry of binuclear $\mathrm{Cu}$ (II) complex. The electronic absorption spectrum of $\left[\mathrm{Ni}_{2}(\mathrm{~L})_{2} \mathrm{Cl}_{4}\right] \cdot 4 \mathrm{H}_{2} \mathrm{O}$ complex show broad band at of $690 \mathrm{~nm}$ and $502 \mathrm{~nm}$, which are assigned to ${ }^{3} \mathrm{~A}_{2(\mathrm{~g})} \rightarrow{ }^{3} \mathrm{~T}_{1 \mathrm{~g}}(\mathrm{~F})$ and ${ }^{3} \mathrm{~A}_{2(\mathrm{~g})} \rightarrow{ }^{3} \mathrm{~T}_{1 \mathrm{~g}}(\mathrm{P})$ transitions, respectively. The absorption spectra of complex also display a band at $378 \mathrm{~nm}$ assigned to charge transfer transition from the ligand to metal ion $(\mathrm{LMCT})^{24}$. These transitions are consistent with an octahedral geometry of $\mathrm{Ni}$ (II) complex ${ }^{25}$. The magnetic moment value $\left(\mu_{\text {eff }}\right)$ of $\mathrm{Ni}(\mathrm{II})$ complex is $1.80 \mu_{\mathrm{B}}$ which indicates the presence of two unpaired electron per $\mathrm{Ni}(\mathrm{II})$ ion and also confirming octahedral geometry of binuclear Ni(II) complex. At room temperature, low $\mu_{\text {eff }}$ value for $\mathrm{Ni}$ (II) complex may be due to a strong $\mathrm{Ni}-\mathrm{Ni}$ interaction. The electronic absorption spectrum of $\left[\mathrm{Co}_{2}(\mathrm{~L})_{2} \mathrm{Cl}_{4}\right] \cdot \mathrm{H}_{2} \mathrm{O}$ complex exhibits absorption bands in the region 780, 598 and $456 \mathrm{~nm}$, which may be assigned to ${ }^{4} \mathrm{~T}_{1 \mathrm{~g}}(\mathrm{~F}) \rightarrow{ }^{4} \mathrm{~T}_{2 \mathrm{~g}}(\mathrm{~F}),{ }^{4} \mathrm{~T}_{1 \mathrm{~g}}(\mathrm{~F}) \rightarrow{ }^{4} \mathrm{~A}_{2 \mathrm{~g}}(\mathrm{~F})$ and ${ }^{4} \mathrm{~T}_{1 \mathrm{~g}}(\mathrm{~F})$ $\rightarrow{ }^{4} \mathrm{~T}_{1 \mathrm{~g}}(\mathrm{P})$ transitions, respectively, indicating octahedral geometry of $\mathrm{Co}$ (II) complex ${ }^{26}$. In addition, a band observed at $382 \mathrm{~nm}$ attributed to charge transfer transition from the ligand to metal ion (LMCT) ${ }^{24}$. Furthermore, octahedral geometry for $\mathrm{Co}(\mathrm{II})$ complex is also supported by its magnetic moment value $\left(\mu_{\text {eff }}\right)$ at room temperature which is $2.62 \mu_{\mathrm{B}}$ per Co atom. The electronic spectrum of $\left[\mathrm{Zn}_{2}(\mathrm{~L})_{2}\left(\mathrm{CH}_{3} \mathrm{CO}_{2}\right)_{4}\right] \cdot 4 \mathrm{H}_{2} \mathrm{O}$ exhibits a band at $372 \mathrm{~nm}$ which may be assigned to transition of charge transfer from the low energy $\pi^{*}$ orbital of the ligand to the $d$-orbitals of $\mathrm{Zn}$ (II) ion (LMCT) ${ }^{24}$. Zn(II) belongs to $d^{10}$ system. So the $\mathrm{Zn}$ (II) complex is diamagnetic because of unavailability of unpaired electrons in this system.

EPR spectra: The X-band spectrum of $\left[\mathrm{Cu}_{2}\left(\mathrm{~L}_{2} \mathrm{Cl}_{4}\right] \cdot 4 \mathrm{H}_{2} \mathrm{O}\right.$ and $\left[\mathrm{Co}_{2}(\mathrm{~L})_{2} \mathrm{Cl}_{4}\right] \cdot \mathrm{H}_{2} \mathrm{O}$ complexes were recorded. The X-band EPR spectrum of $\mathrm{Cu}$ (II) complex was recorded at frequency of $9.1 \mathrm{GHz}$ under the magnetic field strength $3200 \mathrm{G}$ at room temperature $(298 \mathrm{~K})$ and $\mathrm{Co}(\mathrm{II})$ complex at liquid nitrogen temperature $(77 \mathrm{~K})$ as polycrystalline sample. As a consequence of the fast spin relaxation time of high spin $\mathrm{Co}$ (II) ion, the signals are observed only at low temperature. The $\mathrm{g}_{\|}, \mathrm{g}_{\perp}$ and $g_{a v}$ values of both complexes have been calculated by using formula $g_{\text {av }}^{2}=\left(g_{\|}^{2}+2 g_{\perp}^{2}\right) / 3$. The values of EPR parameters $\mathrm{g}_{\|}, \mathrm{g}_{\perp}$ and $\mathrm{g}_{\mathrm{av}}$ for $\mathrm{Cu}(\mathrm{II})$ complex are 2.148, 2.046 and 2.080, respectively. The EPR spectrum of $\mathrm{Cu}$ (II) complex shows a single absorption band. The absence of hyperfine lines in the spectrum of complexes may be due to strong dipolar and exchange interaction between $\mathrm{Cu}(\mathrm{II})$ ions in the unit cell. The trend $g_{\|}>g_{\perp}>2.002$ observed for the complex under study indicates that the unpaired electron is localized in the $d_{x^{2}-y^{2}}$ orbital of $\mathrm{Cu}(\mathrm{II})$ ion $^{27}$. Thus, EPR spectral data are in accordance with distorted octahedral geometry around $\mathrm{Cu}(\mathrm{II})$ ion $^{28}$. The analysis of the EPR spectrum of $\left[\mathrm{Co}_{2}(\mathrm{~L})_{2} \mathrm{Cl}_{4}\right] \cdot \mathrm{H}_{2} \mathrm{O}$ gives $\mathrm{g}_{\|} 2.328, \mathrm{~g}_{\perp} 2.016$ and $\mathrm{g}_{\mathrm{av}}$ 2.2215. The trend $\mathrm{g}_{\|}>\mathrm{g}_{\perp}>2.002$ observed for the $\mathrm{Co}$ (II) complex under study is due to a large angular momentum contribution. The $\mathrm{g}_{\|}>2.3$ is characteristic of an ionic environment and $\mathrm{g}_{\|}<2.3$ indicate a covalent environment in metal ligand bonding. The $g_{\|}$values for both complexes are less than $2.3\left(\mathrm{~g}_{\|}<2.3\right)$, indicates an appreciable metal ligand covalent character ${ }^{29}$. Thus, EPR values also support octahedral geometry of Co(II) complex ${ }^{28}$.

In vitro antibacterial and antifungal activity: In vitro antibacterial and antifungal activity of newly synthesized ligand and its binuclear metal complexes have been tested against the bacteria $B$. subtilis and $E$. coli and fungi $A$. niger and A. flavus. Antimicrobial activity data (Table-3) show that the binuclear metal complexes were more toxic than free ligand. Of the tested compounds, $\left[\mathrm{Cu}_{2}(\mathrm{~L})_{2} \mathrm{Cl}_{4}\right] \cdot 4 \mathrm{H}_{2} \mathrm{O}$ complex shows highest biological activity and $\left[\mathrm{Co}_{2}(\mathrm{~L})_{2} \mathrm{Cl}_{4}\right] \cdot \mathrm{H}_{2} \mathrm{O}$ complex exhibits lowest activity against studied microbes. Such increased activity of the metal complexes can be explained on the basis of chelation theory. On chelation, the polarity of the metal ion will be reduced to a greater extent due to overlap of the ligand orbital and partial sharing of the positive charge of the metal ion with donor groups. Further, it increases the delocalization of $\pi$-electrons over the whole chelate ring and enhances the penetration of the complexes into lipid membranes and blocking of the metal binding sites in enzymes of microorganism. These complexes also disturb the respiration process of the cell and thus block the synthesis of proteins, which restricts further growth of microorganism ${ }^{30}$.

\section{ACKNOWLEDGEMENTS}

The authors are thankful to ACBR, Delhi for providing spectral data, IIT Roorkee, for providing elemental analysis data, SAIF, Punjab University, Chandigarh for providing ${ }^{1} \mathrm{H}$ NMR spectral data and SARC, Meerut for providing biological activity facility. The authors are also thankful to authorities of Meerut College, Meerut for providing necessary research facilities. 


\section{REFERENCES}

1. J.A.R. Navarro and B. Lippert, Coord. Chem. Rev., 222, 219 (2001)

2. M. Sonmez, M. Celebi and I. Berber, Eur. J. Med. Chem., 4, 1935 (2010).

3. S.E.M. Khali, H.S. Saleem, B.A. El-Shetary and M. Shebl, J. Coord. Chem., 55, 883 (2002).

4. T.F. Mastropietro, D. Armentano, E. Grisolia, C. Zanchini, F. Lloret, M. Julve and G.D. Munno, J. Chem. Soc. Dalton Trans., 514 (2008).

5. E. Colacio, J.M. Dominguez-Vera, A. Romerosa, R. Kivekas, M. klinga and A. Escuer, Inorg. Chim. Acta, 234, 61 (1995)

6. M.S. Masoud, E.A. Khalil, A.M. Hindawy, A.E. Ali and E.F. Mohamed, Spectrochim. Acta A, 60, 2807 (2004).

7. M.D. Revenco, O.V. Palamarciuc, P.N. Bourosh, J. Lipkowski, M Gdaniec, Y.A. Simonov and R. Clerac, Inorg. Chim. Acta, 368, 157 (2011).

8. S. Tabassum, G.C. Sharma, F. Arjmand and A. Azam, Nanotechnology, 21, 195102 (2010).

9. N.P. Singh and A.N. Srivastava, E-J. Chem., 8, 809 (2010).

10. K. Kohda, I. Kobayashi, K. Itano, S. Asano and Y. Kawazoe, Tetrahedron, 49, 3947 (1993).

11. C.N. Reilley, R.W. Schmidt and F.A. Sadek, J. Chem. Educ., 36, 619 (1959).

12. A.I. Vogel, A Text Book of Quantitative Inorganic Analysis, Longmans, London, p. 433 (1961)

13. A.K. Sadna, Y. Mirza, A. R. Aneja and O. Prakash, Eur. J. Med. Chem., 38, 533 (2003).

14. W.J. Geary, Coord. Chem. Rev., 7, 81 (1971)

15. M. Dolze, M. Tumer and M. Digrak, Transition Met. Chem., 29, 516 (2004).

16. M.S. Masoud, E.A. Khalil, A.M. Hindway, A.E. Ali and E.F. Mohmed, Spectrochim. Acta A, 60, 2807 (2004).
17. A. Alagha, L. Parthasrathi, D. Gaynor, H.M. Bunz, Z.A. Starikova, E. Farkas, E.C.O. Brien, M.J. Gil and K.B. Nolan, Inorg. Chim. Acta, 368, 58 (2011).

18. K. Nakamoto, Infrared and Raman Spectra of Inorganic and Coordination Compounds, Wiley, New York (1986).

19. R.C. Maurya, J. Chourasia and P. Sharma, Indian J. Chem., 47A, 517 (2008).

20. L.J. Bellamy, The Infrared Spectra of Complex Molecules, Chapmann and Hall, London (1978).

21. M. Sonmez and M. Sekerci, Polish J. Chem., 76, 907 (2002).

22. G. Kumar, D. Kumar, S. Devi, R. Johri and C.P. Singh, Eur. J. Med. Chem., 45, 3056 (2010).

23. R.M. Silverstein, C.M. Bassler and T.C. Morrill, Spectrometric Identification of Organic Compounds, New York: John Wiley, edn. 3 (1974).

24. G. Ferguson, J.N. Low, M. Quiros-Olozabal, J.M. Salas-Peregrin, F. Hueso-Urena and M.N. Moreno-Carretero, Polyhedron, 15, 3233 (1996).

25. A.B.P. Lever, Inorganic Electronic Spectroscopy, Elsevier, New York, edn. 2 (1968).

26. G.G. Mohamed, M.A. Zayed and N.E.A. El-Gamel, Spectrochim. Acta A, 58, 3167 (2002).

27. A.M. Herrera, R.J. Staples, S.V. Kryotov, A.Y. Nazarenko and E. Vakimova, J. Chem. Soc. Dalton Trans., 846 (2003).

28. D.R. Lorenz, J.R. Wasson, D.K. Johonson and D.A. Thorpe, J. Inorg. Nucl. Chem., 37, 2297 (1975).

29. A. Bansal, S. Kumar and R.V. Singh, Synth. React. Inorg. Met. Org. Chem., 31, 1085 (2001).

30. N. Dharmaraj, P. Viswanathamurthi, K. Natarajan, Transition Met. Chem., 26, 105 (2002) 